\title{
Circular Economy Concept in Sustainable Building Design
}

\author{
By Anna Mazzi ${ }^{*} \&$ Beatrice Gatto
}

The European framework directive on waste commits European countries to achieve $70 \%$ reduction in the weight of construction waste, by adoption of reuse, recycling and recovery, avoiding landfill as much as possible. Selective demolition is a realistic alternative to avoid the environmental impacts related to the demolition building: it allows an effective recovery of materials derived from a building demolition, as direct reuse (without any treatment) or recycling (with ad-hoc treatment activities), and it minimizes the amount of waste that must be sent to incineration or landfill (according to their dangerousness). However, selective demolition is still a rare practice today, as demonstrated by the literature review of recent scientific papers. The most frequently methods of processing waste materials on construction and demolition do not have any waste selection system, because a selective demolition is too expansive, and when a building is demolished nobody is willing to pay additional costs for waste selection. Therefore, selective demolition is a viable solution for sustainable management of construction waste only if it is a constructive specification from the building design. To confirm this point of view, the results related to an Italian case study, concerning the environmental and economic impact assessment of demolition activities of a family house are provided; the case study shows that the selective demolition is convenient, compared to traditional non-selective demolition, both from an economic and from an environmental point of view. Hence, the next challenge for sustainable construction includes sustainable demolition criteria in building design.

Keywords: Construction waste, Selective demolition, Environmental impact assessment, Sustainable building design.

\section{Introduction}

In the last decades, in industrialized countries, environmental problems linked to waste production have been increased. In this context, building construction and demolition sector has conquered the supremacy in terms of quantity of waste materials produced.

Recently, international policies recommend reduction of waste production, favoring collection and treatment operations and recovery materials solutions. The greatest challenge today is to rethink the destination of products when their exchange value and use value fail.

Coherently with a modern approach to resources use, recovery and recycling of demolition waste can allow both economic and environmental advantages, as it

\footnotetext{
*Assistant Professor, Department of Industrial Engineering, University of Padova, Italy. ${ }^{\star}$ PhD Student, Department of Civil, Environmental and Architectural Engineering, University of Padova, Italy.
} 
reduces impacts related to waste treatment and raw materials extraction. Circular economy represents the most innovative and promising challenge in the next years in many economic sectors and in the construction sector too: it is a real solution both for environmental problems related to waste management, for economic limits related to raw materials availability. Through this approach, materials contained in products at the end-of-life finish to be considered residues without any use or value, and they are identified as real resources, with new potential uses and corresponding economic value.

In the perspective to reduce waste quantity and to prefer as possible reuse, recovery and recycle, a new waste hierarchy is affirmed and every European country has assumed tangible goals to reduce waste production. This commitment translates in specific targets related to all the economic activities, and the construction sector too. However, statistics and studies show that building materials recovery initiatives are still little widespread in the construction market.

The main goal of this research concerns deepening the circular economy topic applied to Construction \& Demolition Waste (CDW), focusing on the available alternatives for recovery, reuse and/or recycling of materials, in order to reduce environmental impacts related to waste management and raw materials consumption; the research aims also to verify if there is economic convenience to adopt the approach of circular economy in CDW.

The topic's analysis first is carried out with a theoretical focus, based on legislative indications for the European market and the recently published scientific literature; a reasoned synthesis of this first step is reported in the next section. As second step of the research, a real case study is analyzed, a family house designed with good energy performance: The Methodology section summarizes methodological assumptions related to the case study. In the Results section, results of materials' recovery possibilities at demolition stage of family house are presented, and evaluation of economic and environmental benefits resulting from a selective demolition, which allows the recovery of materials, is explained. In the Discussion section, the case study results are discussed, comparing the performance related to conventional and selective demolition. The Conclusions section concludes the paper with final propositions and further recommendations for future research from a perspective of sustainability.

\section{Literature Review}

Construction is one of the main sectors in which is convenient to invest for an environmental improvement through waste reduction and raw materials use decreasing. In order to know the state of the art concerning this topic, two parallel deepening were conducted:

1. Review of international and European recommendations related the waste reduction and management in construction sector.

2. Review of scientific papers concerned building design, construction, renovation and demolition and focused on the waste reduction. 
To conduct the systematic reviews, the methodological recommendations suggested by scientists are followed (Luederitz et al. 2016, Mazzi et al. 2016, Büyüközkan and Karabulut 2018, Mazzi 2019).

In this section, we propose a reasoned summary of these reviews, in order to draw useful indications for conducting the case study.

\section{CDW Management in International and European Recommendations}

The sustainable development represents the challenging goal at international and local level. The concept of sustainability should ideally improve the quality of life for every individual without expending the earth's resources beyond its capacity (Rockström et al. 2009, Steffen et al. 2015). Acting to reduce the impact on the ecosystem is therefore necessary and urgent, needing a collective effort, involving businesses, governments and individuals in the sustainable development agenda (UN 2002).

Compared to other sectors, at the international level, construction sector determines a massive consumption of resources, as raw materials, fresh water and energy. Moreover, this sector causes relevant environmental impacts in terms of solid waste production and greenhouse gases emissions (UNEP 2013). The construction sector assumes a key role to make a sustainable development model.

In designing, manufacturing, delivering, using, recovering and disposing products, the promising strategy must include at the same time a decrease of resources' consumption and a reduction of waste production. With a life cycle perspective, the totality of environmental impacts is considered in the analysis, with a long-term time horizon and a multidimensional view (Mazzi 2020). Going beyond the linear perspective of use-consumption-disposal, the circular economy represents the modern approach that permits to move from "cradle to grave" to "cradle to cradle", in which the products at the end-of-life can represent the starting point for new products as secondary raw materials (EC 2015).

Figure 1 represents the new approach proposed by the European action plan on circular economy through life cycle perspective.

In the perspective to reduce waste quantity and to prefer as possible reuse, recovery and recycle, the European Directive 2008/98/EC on waste (Waste Framework Directive) establishes a new waste hierarchy of waste management (EU 2008). As shown in Figure 2, the waste hierarchy refers to the 5 steps representing a priority order set among waste prevention and management options. First of all, the most effective solution consists in waste minimization, with preventive actions in a product design stage; secondly, reuse using something again it must be considered; as third alternative, recycling can convert waste materials into new materials and objects; then, recovery and disposal represent the last chances in a modern approach of waste management. 
Figure 1. Circular Economy Approach in a Life Cycle Perspective

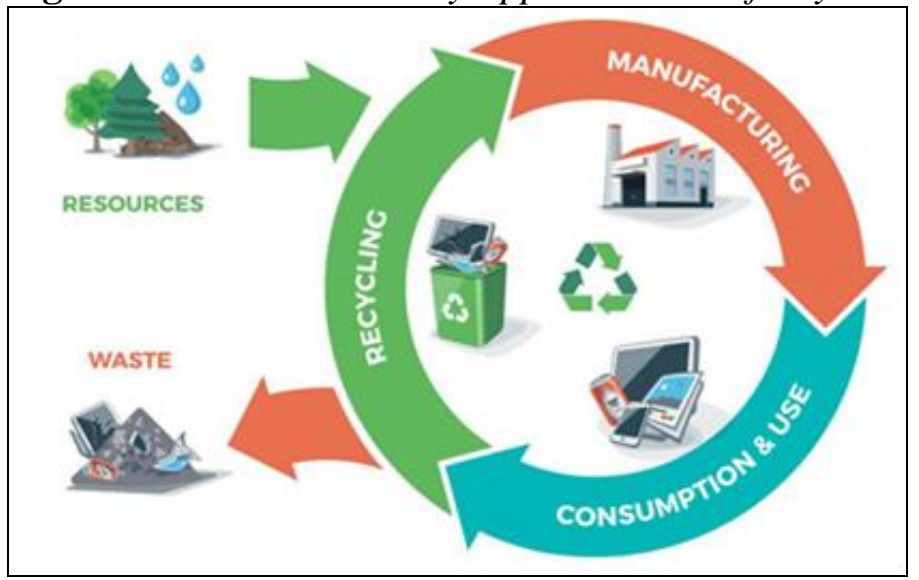

Source: https://ec.europa.eu/jrc/en/news/making-waste-thing-past

Figure 2 European Waste Hierarchy

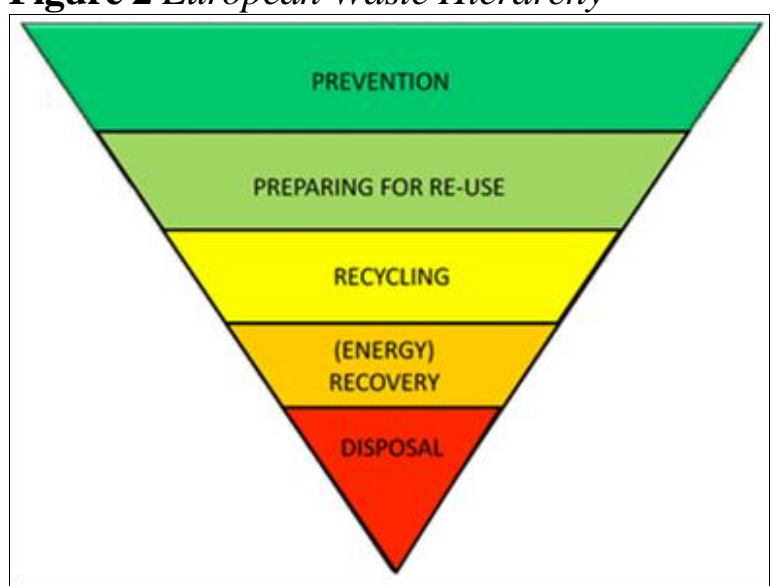

Source: https://epthinktank.eu/2017/05/29/circular-economy-package-four-legislative-proposals-onwaste-eu-legislation-in-progress/waste_hierarchy/

In the last decade, the CDW has been identified as priority area in which to intervene to improve environmental performance. CDWs have a high recovery potential and they can represent real resources as construction materials, thus allowing to avoid the exploitation of natural resources.

CDW includes materials derived by construction, expansion, restoration, reconstruction, modification, and demolition of buildings or other infrastructures. As in the Decision of European Commission 2000/532/CE, CDW is made up of several types of products, often very heterogeneous (EC 2000):

- concrete, tiles, bricks, ceramics;

- wood, plastic, glass;

- bituminous mixtures, asphalt, tar;

- excavation materials (including those from contaminated sites), rocks, materials from dredging;

- insulating materials;

- building materials containing asbestos; 
- gypsum-based building materials;

- other construction materials.

According to data provided by European reports (EC 2011), the potential reuse/recycle of CDW is included from $10 \%$ to $90 \%$. Based on the indications from the European Waste Framework Directive (EU 2008), by 2020, 70\% by weight of non-hazardous materials of construction and demolition sites must be reused or recycled or recovered, and the landfilling is to be avoided. Reuse and recycle of CDW is made necessary above all by the pauperization of natural resources and, secondly, by the limited space availability for landfilling.

Valorization of wastes in a circular economy approach brings both environmental and economic benefits. For this reason, innovative technologies for separation and recycling of CDW are being developed (EU 2018a).

However, although the European policies have introduced very ambitious CDW recovery targets, the performance of European countries is very different today, and in some countries, including Italy, the current CDW recovery capacity is less than $10 \%$ in weight (EC 2011).

\section{CDW Management in Scientific Literature}

Coherently with European recommendations of waste hierarchy, through an ad-hoc literature review it is possible to verify how CDW management actions are preferred at theoretical and practical level.

The following considerations derive from the analysis of the main papers recently published in scientific journals concerning this topic (Ajayi et al. 2017, Ju et al. 2016, Martinez et al. 2013, Martinez et al. 2016, Saghafi and Teshnizi 2011, Sandin et al. 2014, Vasquez et al. 2016).

Moreover, possible solutions for recovery, reuse and recycling of CDW are summarized from the European guidelines published in the last few years (EC 2011, Ecorys 2016, EU 2018a, 2018b).

\section{Possible End-of-Life Scenarios of Buildings}

Scientific literature agrees that possible end-of-life scenarios of a building are renovation, recycling and demolition.

i. Renovation

It is the more efficient solution to reduce environmental impacts, because most of the materials in situ are used for other scenarios. The starting structure is kept intact, while the construction works are limited to modify and improve the building's function. With reference of European waste hierarchy represented in Figure 2, the renovation corresponds to "preparing for reuse". This solution is frequently preferable, especially in densely urbanized areas such as European cities. However, building renovation too produces CDWs that could be recovered in a circular perspective, but frequently wastes from renovation activities are not separately collected, then they are removed without recovery. 
ii. Building recycling

It represents the second possible scenario. To be effective, it should already be planned in the building design phase, in order to make the correct separation of the materials for their recovery during the demolition phase. In other words, in building end-of-life the recycling is a real opportunity only if there is a design for recycling. Building is dismantled, so products and materials are recovered for other uses in new products or components.

Different recovery solutions are presented in the next subsection.

With reference of European waste hierarchy in Figure 2, the scenario of building recycling corresponds to "recycling" with "prevention" and in some case with "preparing for reuse".

\section{iii. Demolition}

It is the third scenario of building end-of-life. There are two different type of demolition: selective and conventional.

Selective demolition of building follows the European waste hierarchy and tries to make the most of the possibility of recovery, reuse and recycling of demolition materials, in order to minimize the landfilling. There are different solutions to recover CDW, based on the materials' characteristics, as described in the Emerging findings from literature review subsection. Selective demolition corresponds, in the waste hierarchy in Figure 2, to solutions "recycling" and "energy recovery".

On the contrary, conventional demolition implies the landfilling without waste separation and without any materials' reuse/recovery option. This alternative corresponds to the final step of EU waste hierarchy (Figure 2), "landfilling", and then it should be the least preferable alternative.

Figure 3. The Circular Economy in Building Sector

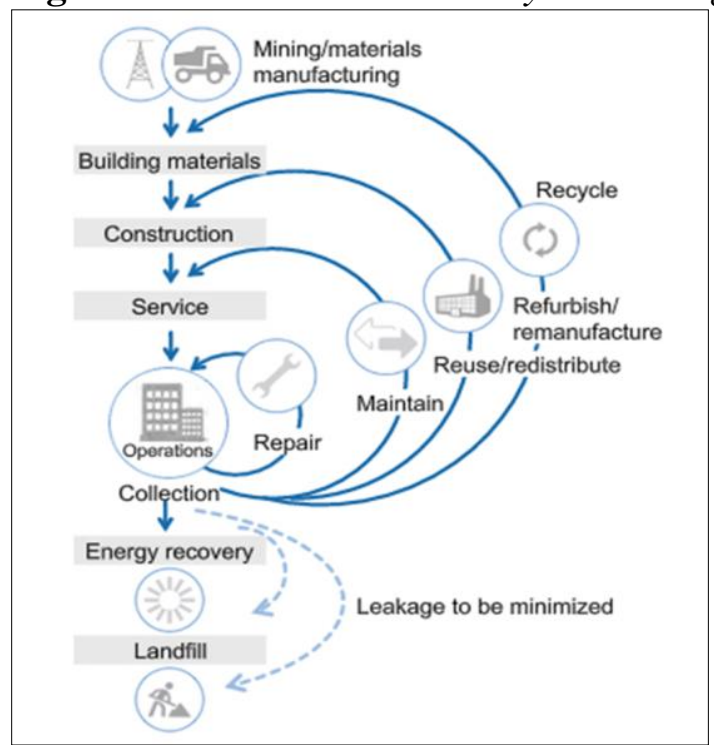

Source: WEF 2016 
The emerging approach recommended by the scientific community and international regulations about the end-of-life scenarios of buildings will be represented in Figure 3, in which the circular economy represents not only a chance to reduce the environmental impacts of DCW, but a real opportunity for economic savings and profit.

Material Recovery in Building Recycling and in Selective Demolition

From scientific considerations and European recommendations, there are different possible recovery solutions of products and materials derived by renovation or demolition processes.

a) Product recycling: glass, bricks, beams that can be reused as they are, without chemical and/or physical treatments; environmental benefits of this option include raw materials saving and energy saving.

b) Material recycling: materials and components (for example, wooden beans) that can be recovered with chemical and/or physical treatments and processing for recycling, in order to obtain adequate performance for the new use; environmental benefits of this option include raw materials saving, but imply energy and water consumption.

c) Feedstock recycling: disassembled material that can be treated to make secondary raw material, so as to replace natural raw material in the construction phase or in other industrial sectors.

d) Energy recovery: other residual materials that technically cannot be recovered in other ways; environmental benefits of this solution are very limited, including only energy recovery through incineration processes.

e) Final disposal with energy recovery: residual materials with chemicalphysical characteristics that prevent recovery and incineration, for safety and health protection reasons; in this case, the only advantage is a precaution approach for health risks.

Now, the European waste hierarchy reported in Figure 2 can be rewritten for the CDW management, as represented in Figure 4; in the inverted pyramid, the preferable typologies of recovery are those which involve less processing on the waste products and materials, while energy recovery is to be considered the last chance to use the CDW.

\section{Emerging Findings from Literature Review}

From the literature review, there are several scenarios of building's end-oflife, and some of these are more coherent with the European waste hierarchy.

Firstly, the design phase represents the most important decisional phase, because it determines the main environmental impacts of following life cycle phases, as construction, use and disposal of building.

Secondly, in line with the circular economy, preferable end-of-life scenarios in terms of recovery materials chances are building renovation, building recycling and selective demolition. 
However, selective demolition and recycling of CDW are rarely adopted by companies. These solutions seem to be more theoretical options than actually achievable actions.

Figure 4. European Waste Hierarchy Rewritten in CDW Management Sector

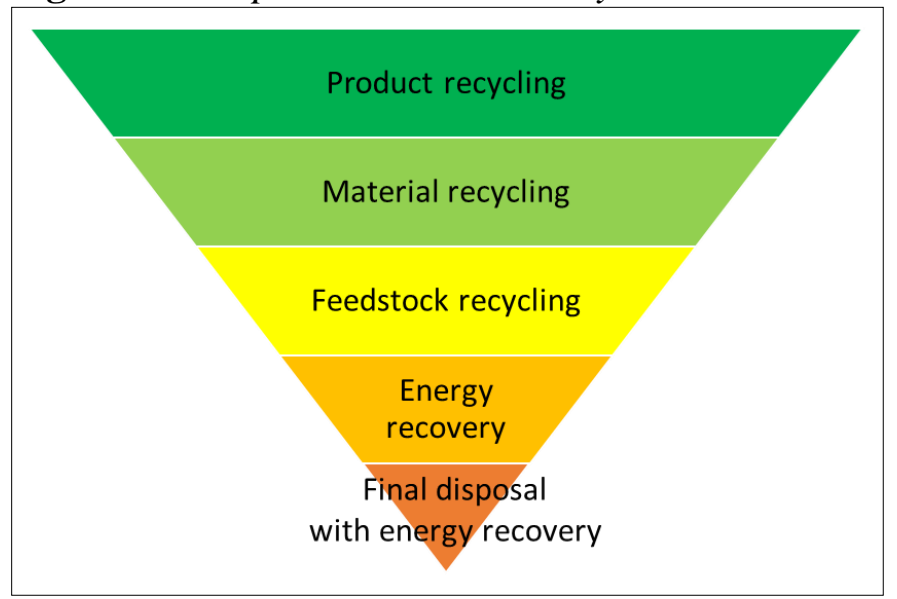

Source: Authors' Elaboration.

\section{Methodology}

\section{Research Goal and Scope}

Focusing on the emerging findings from the literature review, as second research step a real case study is considered, in order to verify the effective applicability of recovery/recycling hypotheses previously summarized.

The selected case study is the operational project to realize a family house located in the north-east of Italy.

Research goals include to verify if there are and if yes, how many are the environmental and economic benefits in terms of recovery and recycling of CDW at the building's end-of-life. Environmental and economic performance of two alternative solutions of CDW management are compared: conventional demolition with landfilling of non-selected waste (worst case), and selective demolition with recovery of selected materials (best case).

\section{Description of Case Study}

The building has plan dimensions of $12.50 \mathrm{~m}$ per $12.50 \mathrm{~m}$ and maximum height above ground of $10 \mathrm{~m}$. It consists of a basement, two floors above ground and a small attic. The basement is made of stalls and load-bearing reinforced concrete walls, and with two internal pillars of reinforced concrete. The supporting structure in elevation of the ground floor consists of brick masonry with reinforced concrete beams and curbs, on which the two-pitched wooden roof rests. The first and second floors are made of laminated wood beams and double crossed wooden planks, fixed on beams/curbs in reinforced concrete by means of hidden metal 
brackets. The roof consists of 4 triangular trusses in which the struts are made of coupled wooden beams while the chain consists of the beams of the second and third floors. The infills of the first and attic floor are made of wood with platformframe panels. The internal walls are in plasterboard, the windows are made of wood and double glazing. The perimeter walls, the interior walls and the roof are insulated with insulating materials. The electrical system is concealed with corrugated plastic protective tubes and copper conductors coated in turn with insulating plastic material. The heating system has been realized with copper pipes covered with insulating material, the heating system is on the floor, complete with insulation panels and plastic pipes. The exhaust system is made of plastic material. The building is equipped with a photovoltaic system. Sheaths to waterproof roof and roofs, flashings, gutters and downpipes in aluminum complete the building.

Figure 5 represents the 3D model of the building object of the study.

Figure 5. 3D Model of the Building Object of the Study

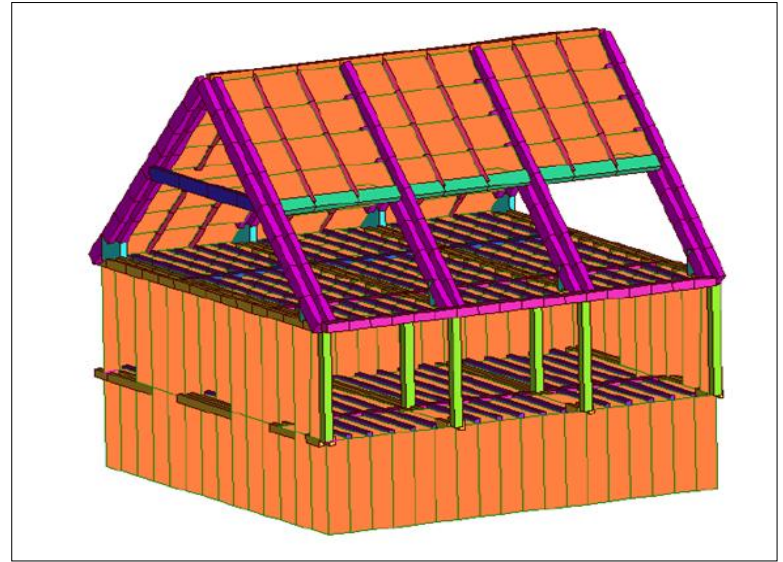

Source: Project Documentation of the Case Study.

\section{Research Steps and Methodological Framework}

The basic idea of research methodology is the matter balance in a life cycle perspective: the amount of materials estimated in the design phase to realize the building corresponds to amount of materials derived by the demolition phase, in the end-of-life of building. In other words, in the case study, construction materials in the design phase will represent the CDW at the demolition stage (from cradle to grave).

Consequently, to analyze the environmental and economic hotspots associated to conventional and selective demolition of a family house, the reasoning considers all the components of building construction. As shown in Figure 6 , for the main construction materials the quantity and density will be considered; consequently, the weight of materials necessary to build the house will be calculated. Based on the weight of materials, the economic value of materials constituting the building will be deduced. Then, the costs and revenues of demolition process will be estimated, in alternative solutions, conventional demolition (worst case, without material recycling) and selective demolition (best case, with material recycling). 
Figure 6. Methodological Framework in the Research Case Study



Source: Authors' Elaboration.

\section{Results}

Preliminary Information about the Case Study

Considering project data of case study, the amount of necessary materials to construct the family house is estimated. These materials will represent also the CDW in the end-of-life of building, at demolition stage that will be landfilled in conventional demolition (worst case) and recycled in selective demolition (best case).

Starting from project documentation of case study, data relating to metric calculation of family house are summarized in Table 1, specifying the dimensions of each surface.

Table 1. Metric Calculation of Family House and Dimensions of Surfaces

\begin{tabular}{|l|c|}
\hline Elements & $\mathbf{~ m}^{\mathbf{2}}$ \\
\hline Coverage & 187.03 \\
\hline Attic floor & 74.75 \\
\hline Slab 2 & 132.25 \\
\hline Slab 1 & 132.25 \\
\hline Walls first floor & 69.00 \\
\hline Walls ground floor & 184.00 \\
\hline Underground walls & 166.75 \\
\hline Foundations & 144.00 \\
\hline
\end{tabular}

Source: Project Documentation of the Case Study. 
Table 2. Volume, Density, Weight and Costs of End-Of-Life Treatments of Materials Grouped according to the Construction Elements

\begin{tabular}{|c|c|c|c|c|c|}
\hline $\begin{array}{l}\text { Construction } \\
\text { elements }\end{array}$ & Materials & $\begin{array}{c}\text { Volume } \\
\left(\mathbf{m}^{3}\right)\end{array}$ & $\begin{array}{l}\text { Density } \\
\left(\mathrm{kg} / \mathrm{m}^{3}\right)\end{array}$ & $\begin{array}{c}\text { Weight } \\
(\mathbf{k g})\end{array}$ & $\operatorname{Cost}(€)$ \\
\hline \multirow{5}{*}{ Roofing } & Rubble (clay tiles) & 4.00 & $1,500.00$ & $6,000.00$ & 900.00 \\
\hline & $\begin{array}{c}\text { Iron and steel } \\
\text { (screws, bolts, nails) }\end{array}$ & 0.02 & $7,850.00$ & 150.00 & $0.00 *$ \\
\hline & Bituminous sheath & - & $1,200.00$ & - & - \\
\hline & $\begin{array}{l}\text { Wood (laminated, } \\
\text { solid, planked) }\end{array}$ & 27.39 & 600.00 & $16,434.00$ & $1,972.00$ \\
\hline & $\begin{array}{l}\text { Insulating materials } \\
\text { (rock wool, vapor } \\
\text { barrier, vapor brake) }\end{array}$ & 22.44 & 150.00 & $3,360.00$ & $1,478.00$ \\
\hline \multirow{5}{*}{$\begin{array}{l}\text { Slabs (attic, } \\
\text { first floor, } \\
\text { second floor) }\end{array}$} & Rubble (clay tiles) & 9.09 & $1,500.00$ & $13,635.00$ & $2,045.00$ \\
\hline & Iron and steel & 0.02 & $7,850.00$ & 181.80 & $0.00 *$ \\
\hline & Bituminous sheath & - & $1,200.00$ & - & - \\
\hline & $\begin{array}{l}\text { Wood (laminated, } \\
\text { solid, planked) }\end{array}$ & 42.38 & 600.00 & $25,428.00$ & $3,051.00$ \\
\hline & Insulating materials & 97.80 & 150.00 & $14,670.00$ & $6,454.00$ \\
\hline \multirow{5}{*}{$\begin{array}{l}\text { Walls } \\
\text { (ground floor } \\
\text { and first } \\
\text { floor) }\end{array}$} & Rubble (clay tiles) & 46.00 & $1,500.00$ & $69,000.00$ & $10,350.00$ \\
\hline & Iron and steel & 5.85 & $7,850.00$ & $4,600.00$ & $0.00 *$ \\
\hline & Bituminous sheath & - & $1,200.00$ & - & - \\
\hline & $\begin{array}{c}\text { Wood (prefabricated } \\
\text { panels) }\end{array}$ & 17,25 & 600.00 & $10,350.00$ & $1,242.00$ \\
\hline & Insulating materials & 25.65 & 150.00 & $3,847.50$ & $1,692.00$ \\
\hline \multirow{5}{*}{$\begin{array}{l}\text { Underground } \\
\text { and } \\
\text { foundations }\end{array}$} & Rubble (clay tiles) & 112.58 & $1,500.00$ & $168,870.00$ & $25,330.00$ \\
\hline & Iron and steel & 1.53 & $7,850.00$ & $12,087.00$ & $0.00 *$ \\
\hline & Bituminous sheath & 1.25 & $1,200.00$ & $1,500.00$ & 540.00 \\
\hline & Lamellar wood & - & 600,00 & - & - \\
\hline & Insulating materials & 54.70 & 150.00 & $8,205.00$ & $3,610.00$ \\
\hline \multirow{4}{*}{ Other } & Hazardous waste & 2.50 & 650.00 & $1,625.00$ & 195.00 \\
\hline & Drywall & 2.83 & 760.00 & $2,151.50$ & 839.00 \\
\hline & $\begin{array}{c}\text { PVC plastic (plaster } \\
\text { holder net) }\end{array}$ & 0.09 & $1,400.00$ & 126.00 & 49.00 \\
\hline & Double glazing & 0.42 & $2,600.00$ & $1,073.00$ & 129.00 \\
\hline \multirow{2}{*}{$\begin{array}{l}\text { Thermal and } \\
\text { heating } \\
\text { systems }\end{array}$} & $\begin{array}{c}\text { Thermal and } \\
\text { electrical system }\end{array}$ & n.r. $* *$ & n.r. ** & n.r. ** & $3,500.00$ \\
\hline & Photovoltaic system & n.r. $* *$ & n.r. $* *$ & n.r. $* *$ & 240.00 \\
\hline Total costs & - & - & - & - & $63,616.00$ \\
\hline
\end{tabular}

\section{Costs of CDW Treatment in Conventional Demolition (Worst Case)}

Knowing the thicknesses of various construction components, the quantities of materials used in the construction phase in various construction elements are calculated. On the base of materials' density in average value, their weight is also 
obtained. Based on the quantities of materials used, the economic value of building materials at the demolition phase is defined.

Estimated volumes and costs are shown in Table 2. It is notable that, even if the conventional demolition supposes a non-selected collection of CDW to send it to landfilling, realistically it is necessary to assume that iron and steel will be selected and recovery in the case study, because their recovery and resale in recycling market is convenient in the Italian context.

The summa of costs associated to the CDW management in conventional demolition of the case study (worst case) is reported in Table 3. Overall costs include: costs of materials' landfilling (derived by Table 2), costs for disposal of non-recycled materials (estimated by considering the materials in Table 2 and including both the costs for landfilling services and transportation to landfill), the costs of labor for demolition operations (estimated by considering the mean of labor's cost in the north-Italy and including the costs to make safety of the area during the demolition period), and the revenues of recovered materials (derived by Table 2).

Table 3. Overall Costs Related to Conventional Demolition (Worst Case)

\begin{tabular}{|l|c|}
\hline Type of costs & Costs (€) \\
\hline Costs for disposal of non-recycled materials (included transport) & about 69,000 \\
\hline Costs of labor for demolition (about 20 man days) & about 4,800 \\
\hline Revenues of recovered materials & - \\
\hline Total costs & about 73,800 \\
\hline
\end{tabular}

Source: Estimation of Authors.

Costs and Benefits of CDW Treatment in Selective Demolition with Recovery and Recycling of Materials (Best Case)

With a circular perspective, most of the materials obtained from building demolition, if recovered in the demolition process, can become a profit rather than a cost. Obviously, recovery is only possible if effective material separation systems are adopted during demolition operations on site: this is possible if the building has been designed considering selective demolition techniques. Moreover, the selective demolition necessarily requires a much longer time than demolition without recovery.

It is difficult to exactly quantify the environmental and economic benefits associated with demolition with recovery. However, thanks to the scientific literature, it is possible to draw a summary of the main economic and environmental advantages associated with selective demolition (Marrero et al. 2017, Marzouk and Azab 2014, Ramage et al. 2017, Rodriguez et al. 2016, Vieira and Pereira 2015). Table 4 synthesizes the main potential environmental and economic advantages derived by a recovery and recycling of CDW related to the case study.

Summarizing the overall costs related the CDW management in the case of selective demolition (best case), the values obtained are shown in Table 5, in which are included: the costs for disposal of non-recycled materials (derived by Table 4 and including both the costs for landfilling services and transportation to 
landfill), the costs of labor for selective demolition operations (estimated by considering the mean of labor's cost in the north-Italy and including the costs to make safety of the area during the demolition period), and the revenues of recovered materials (derived by Table 4 and based on the Italian market price).

From the comparison of data in Tables 3 and 5, we can underline that the time needed to carry out selective demolition is about four times longer than conventional demolition. On the other hand, the revenues associated to sale of recyclable materials are significantly higher than the cost of labor.

Table 4. Potential Benefits from Reuse/Recycle of CDW of Family House

\begin{tabular}{|c|c|c|c|c|}
\hline $\begin{array}{l}\text { Reusable/ } \\
\text { recyclable } \\
\text { materials }\end{array}$ & Steel & Wood & $\begin{array}{c}\text { Insulating } \\
\text { materials: rock } \\
\text { \& glass wool, } \\
\text { polyurethane }\end{array}$ & $\begin{array}{l}\text { Concrete and } \\
\text { inert materials }\end{array}$ \\
\hline $\begin{array}{l}\text { Avoided } \\
\text { waste } \\
\text { treatment } \\
\text { processes }\end{array}$ & $\begin{array}{l}\text { Treatment of } \\
\text { materials with } \\
\text { resins, paints, } \\
\text { glues }\end{array}$ & $\begin{array}{c}\text { Total recovery } \\
\text { of material }\end{array}$ & Pulverization & $\begin{array}{l}\text { Separation and } \\
\text { crushing }\end{array}$ \\
\hline $\begin{array}{l}\text { Avoided } \\
\text { environ- } \\
\text { mental } \\
\text { impacts }\end{array}$ & $\begin{array}{l}\text { Raw material } \\
\text { saving }\end{array}$ & $\begin{array}{l}\text { Avoiding the } \\
\text { extraction of the } \\
\text { virgin one, } \\
\text { reduction of } \\
\text { fossil fuel } \\
\text { consumption, } \\
\text { and CO2 } \\
\text { emissions }\end{array}$ & $\begin{array}{l}\text { Harmful fibers } \\
\text { emissions, raw } \\
\text { material saving }\end{array}$ & $\begin{array}{l}\text { Significant raw } \\
\text { material saving }\end{array}$ \\
\hline $\begin{array}{l}\text { Products } \\
\text { made with } \\
\text { recycled } \\
\text { material }\end{array}$ & $\begin{array}{l}\text { Products made } \\
\text { with recycled } \\
\text { material with } \\
\text { lower } \\
\text { performance }\end{array}$ & $\begin{array}{c}100 \% \\
\text { recyclable } \\
\text { material, with } \\
\text { maintenance of } \\
\text { the chemical- } \\
\text { physical } \\
\text { properties }\end{array}$ & $\begin{array}{c}\text { Composite } \\
\text { insulating panels } \\
\text { with variable \% } \\
\text { of recycled } \\
\text { material }\end{array}$ & $\begin{array}{l}\text { New products } \\
\text { with } \\
\text { performance } \\
\text { dependent of } \% \\
\text { of recycled } \\
\text { materials }\end{array}$ \\
\hline $\begin{array}{l}\text { Economic } \\
\text { benefits } \\
\text { from } \\
\text { recovery/ } \\
\text { recycling }\end{array}$ & $\begin{array}{c}\text { Economic } \\
\text { benefits by } \\
\text { sale of } \\
\text { recycled } \\
\text { material } \\
\text { Costs saving in } \\
\text { raw material } \\
\text { purchasing }\end{array}$ & $\begin{array}{c}\text { Economic } \\
\text { benefits by sale } \\
\text { of recycled } \\
\text { material } \\
\text { Costs saving in } \\
\text { raw material } \\
\text { purchasing }\end{array}$ & $\begin{array}{l}\text { Costs saving in } \\
\text { raw material } \\
\text { purchasing }\end{array}$ & $\begin{array}{c}\text { Relevant waste } \\
\text { treatment costs } \\
\text { savings }\end{array}$ \\
\hline $\begin{array}{l}\text { Economic } \\
\text { costs from } \\
\text { recovery/ } \\
\text { recycling }\end{array}$ & $\begin{array}{l}\text { Products made } \\
\text { with recycled } \\
\text { material with } \\
\text { lower } \\
\text { performance }\end{array}$ & $\begin{array}{l}\text { Processing of } \\
\text { recycled } \\
\text { material } \\
\text { requiring high } \\
\text { energy } \\
\text { consumption } \\
\end{array}$ & $\begin{array}{l}\text { Complex } \\
\text { recycling } \\
\text { processes } \\
\text { requiring high } \\
\text { costs }\end{array}$ & $\begin{array}{l}\text { Low processing } \\
\text { costs }\end{array}$ \\
\hline
\end{tabular}

Source: Elaboration of Authors from Case Study and referenced scientific papers. 
Table 5. Overall Costs Related to Selective Demolition (Best Case)

\begin{tabular}{|l|c|}
\hline Type of Costs & Costs (€) \\
\hline Costs for disposal of non-recycled materials (included transport) & about 3,000 \\
\hline Costs of labor for demolition (about 80 man days) & about 19,200 \\
\hline Revenues of recovered materials & $\begin{array}{c}\text { about } 50,000 \\
(80,000) *\end{array}$ \\
\hline Total costs & $\begin{array}{c}\text { about }-27,800 \\
(-57,800) *\end{array}$ \\
\hline *revenues dependent on the variability of market value of recyclable materials \\
\hline
\end{tabular}

Source: Estimation of Authors.

\section{Discussion}

For the case study the costs and revenues of the two alternatives, conventional demolition (worst case) and selective demolition (best case), are compered, giving an economic value to disposal and recovery opportunities listed in the previous subsections.

In Figure 7, the main costs and revenues related to demolition solutions are compared. The conventional demolition (worst case, orange bars) determines only costs to manage the demolition waste. On the contrary, the selective demolition (best case, green bars) determines also revenues, related the sale of recovered materials. The balance of economic costs is evidently favorable to the selective demolition, even if the time of demolition is double.

It should be emphasized that we have not assigned an economic value to the environmental impacts deriving from the failure to recover the materials. If you give economic value to environmental impacts, the results are extremely supportive of selective demolition.

Figure 7. Comparison of Costs and Revenues Related Conventional and Selective Demolition

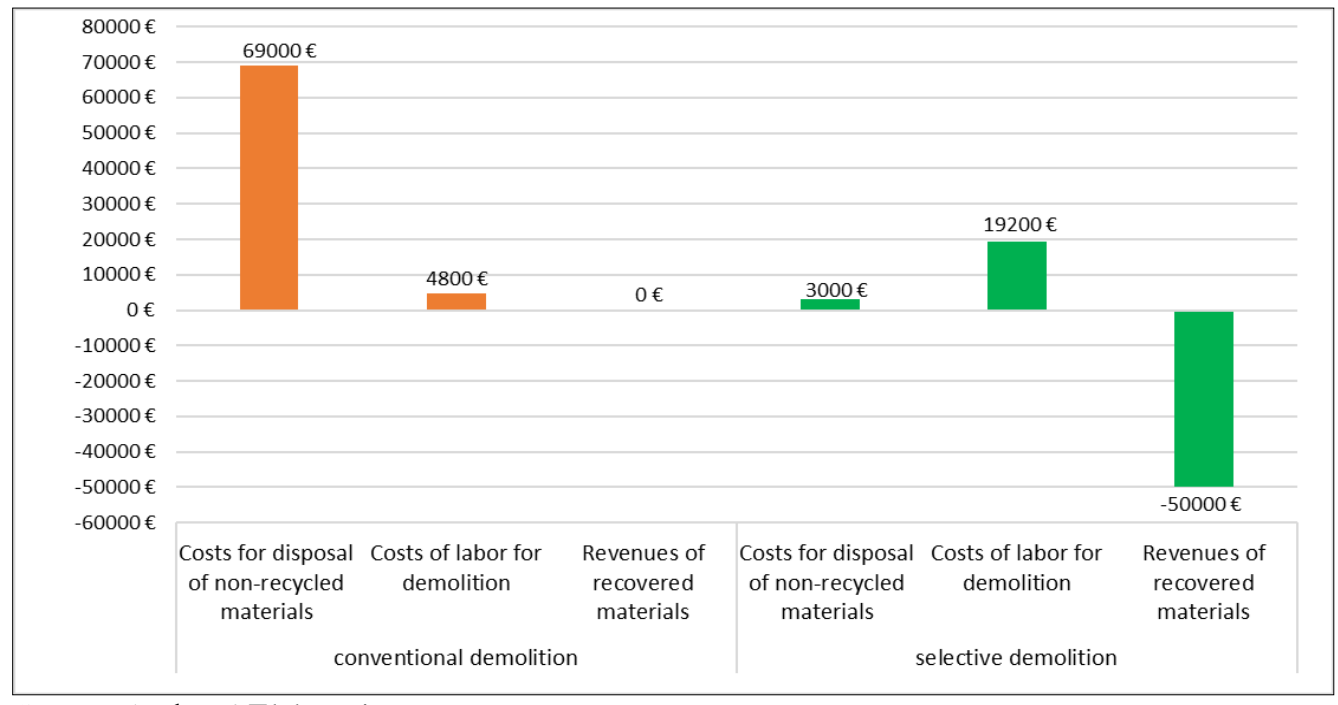

Source: Authors' Elaboration. 
Finally, in order to understand the relevance of costs and revenues related the conventional and selective demolition, it is interesting to consider the price of the house on market. The reference adopted to define the market price of family house is the value per $\mathrm{m}^{2}$ in the real estate market in the north-east of Italy: considering a new building in energy class $A$, the market value varies from $€ 1,100$ to $€ 1,200$ per $\mathrm{m}^{2}$. In our case study, the size of family house is $340.50 \mathrm{~m}^{2}$, of which 273 of ground floor, first and attic, and 134 of basement that for cost evaluation is halved. Then, the market value of family house is around $€ 370,000$.

Figure 8 shows the balance of overall costs and revenues of building demolition, compared to market price of family house. The costs associated to conventional demolition (worst case, orange bars) amount to about $20 \%$ of the market price of family house. On the contrary, the selective demolition (best case, green bars) potentially allows revenue of about $7.5 \%$ of house's market price. Clearly, this hypothesis can only be effectively explored if a selective demolition has been planned during the design phase, i.e. the building elements are easily disassembled and the CDW materials can be easily differentiated.

Figure 8. Comparison between Costs/Revenues of Conventional and Selective Demolition and Sale Price of the Family House

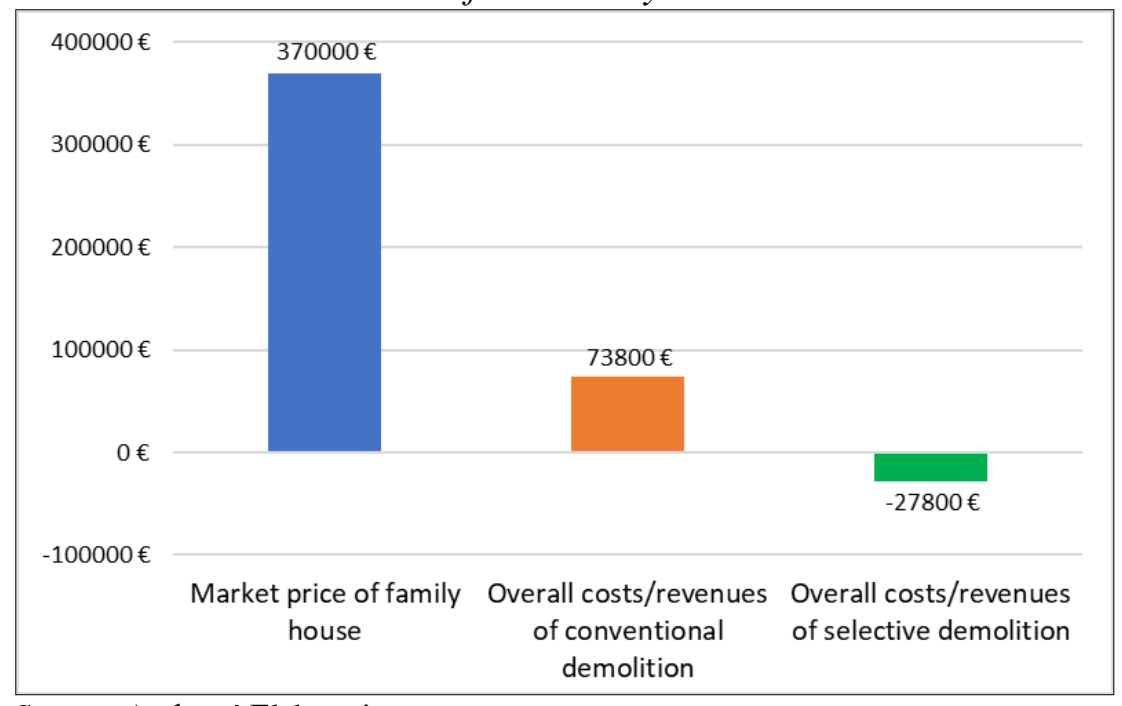

Source: Authors' Elaboration.

\section{Conclusions}

As a rule, already during the construction phase of a building, $10 \%$ by volume of materials becomes waste, which generally without too many scruples is taken to landfill without making any separation. Even the use phase of a building contributes to reducing the consumption of resources, in particular energy consumption, thanks to structural solutions and choices of materials that allow energy efficiency. However, the most significant contribution of CDW production is given by the end-of-life phase of a building: its demolition. Therefore, in order to pursue the goal of CDW recovery it is necessary to resort to strategies that allow 
the improvement of the efficiency of the end-of-life of buildings already in the design phase.

Some solutions proposed in the literature are the possibility of disassembling the building and the lean construction. Using prefabricated structures is a costeffective alternative from both an environmental and economic point of view, as it reduces costs and lead times and reduces material waste by approximately $50 \%$.

The environmental impacts of the building life cycle could be further reduced if the structural components of the building were designed to be reusable. Furthermore, to ensure the recovery of materials, labeling systems should be introduced, so as to ensure optimal reuse after the deconstruction or demolition phase.

Results related to the research case study demonstrate that a sustainable management of demolition waste can also represent an important economic advantage, since the end-of-life landfilling of CDW without recovery or recycling involves at least $20 \%$ of the purchase value of a house.

On the contrary, a selective demolition, that favors the recovery and recycling of materials in line with the circular economy, would entail undoubted environmental advantages but also evident economic benefits: there is the possibility of reducing demolition costs and obtaining further revenues from sale of recycling materials, even if the time needed to carry out a selective demolition is about four times longer than a conventional demolition.

Selective demolition is a technique to manage the end-of-life of building that has both environmental and economic advantages. However, it must be prepared from the planning stages, to be effectively applicable at the end-of-life of building.

Although there are solutions to reduce waste and to increase the possibility of recovery and recycling of materials, conventional demolition is often preferred to deconstruction techniques or selective demolition. In fact, companies limit themselves to evaluating the practical aspect, and identify in the conventional demolition the least expensive, fastest and most expensive solution, without evaluating related environmental impacts and potential economic advantages associated with material recovery.

The chances of recovery and recycling of CDW are constantly evolving, there are more and more research in this area. The international community and the European Union are investing great resources to develop innovative solutions in recovering and recycling of construction materials, pursuing the dual objective: reducing the waste production and reducing raw materials extraction.

Therefore, this topic will have a growing interest, both at scientific and at enterprise level, because the prospects to develop knowledge and technology are promising, and the applications in construction sector are convenient both environmentally and economically.

\section{References}

Ajayi SO, Oyedele LO, Akinade OO, Bilal M, Alaka HA, Owolabi HA, Kadiri KO (2017) Attributes of design for construction waste minimisation: a case study of waste-to- 
energy project. Renewable and Sustainable Energy Reviews 73(Jun): 1333-1341. Doi=https://doi.org/10.1016/j.rser.2017.01.084.

Büyüközkan G, Karabulut Y (2018) Sustainability performance evaluation: literature review and future directions. Journal of Environmental Management 217(Jul): 253267. Doi=https://doi.org/10.1016/j.jenvman.2018.03.064.

EC (2000) Commission Decision replacing decision 94/3/EC establishing a list of wastes pursuant to article 1(a) of council directive 75/442/EEC on waste and council decision 94/904/EC establishing a list of hazardous waste pursuant to article 1(4) of council directive 91/689/EEC on hazardous waste. Bruxelles: European Commission, Commission Decision 2000/532/EC. Retrieved from https://bit.ly/ 2tbDtZL.

EC (2011) Management of CDW in the EU - requirements resulting from the waste framework directive and assessment of the situation in the medium term. Bruxelles: European Commission, Directorate General for Internal Market, Industry, Entrepreneurship and SMEs, Directorate C Industrial Transformation and Advanced Value Chains, C.1 Clean Technologies and Products. Retrieved from https://bit.ly/ 2FHXqd9.

EC (2015) Closing the loop - an EU action plan for the circular economy. Bruxelles: Communication from the Commission to the European Parliament, the Council, the European Economic and Social Committee and the Committee of the Regions, COM/2015/0614 final. Retrieved from https://bit.ly/2NhLEdO.

Ecorys (2016) EU construction \& demolition waste management protocol. Bruxelles: European Commission, Directorate-General for Internal market, Industry, Entrepreneurship and SMEs.

EU (2008) European directive 2008/98/EC of 19 November 2008 on waste and repealing certain directives. Bruxelles: European Parliament and Council of the European Union. Retrieved from https://bit.ly/2NmheHh.

EU (2018a) Construction and demolition waste protocol and guidelines. Bruxelles: European Commission. Retrieved from https://bit.ly/2tTiU4p.

EU (2018b) Development and implementation of initiatives fostering investment and innovation in construction and demolition waste recycling infrastructure. Bruxelles: European Commission, Directorate General for Internal Market, Industry, Entrepreneurship and SMEs, Directorate C Industrial Transformation and Advanced Value Chains, C.1 Clean Technologies and Products. Retrieved from https://bit.ly/ 2RcJ8qh.

Ju C, Ning Y, Pan W (2016) A review of interdependence of sustainable building. Environmental Impact Assessment Review 56(Jan): 120-127. Doi=https://doi.org/10. 1016/j.eiar.2015.09.006.

Luederitz C, Meyer M, Abson DJ, Gralla F, Lang DJ, Rau AL, von Wehrden H (2016) Systematic student-driven literature review in sustainability science - an effective way to merge research and teaching. Journal of Cleaner Production 119(Apr): 229235. Doi=https://bit.ly/2NkYKHj.

Marrero M, Puerto M, Camacho CR, Guerrero AF, Guzmàn JS (2017) Assessing the economic impact and ecological footprint of construction and demolition waste during the urbanization of rural land. Resources, Conservation and Recycling 117(Feb): 160-174. DOI=https://bit.ly/2QQaWSG.

Martinez E, Nunez Y, Sobaberas E (2013) End of life of buildings: three alternatives, two scenarios. A case study, International Journal of LCA 18(Mar): 1082-1088. Doi= https://doi.org/10.1007/s11367-013-0566-4.

Martinez PS, Cortina MG, Martìnez FF, Sànchez AR (2016) Comparative study of three types of fine recycled aggregates from constuction and demolition waste (CDW), and 
their use in mansory mortar fabrication. Journal of Cleaner Production 118(Apr): 162-169. Doi=https://bit.ly/2QLZQOk.

Marzouk M, Azab S (2014) Environmental and economic impact assessment of construction and demolition waste disposal using system dynamics. Resources, Conservation and Recycling 82(Jan): 41-49. Doi=https://doi.org/10.1016/j.resconrec. 2013.10.015.

Mazzi A (2019) Environmental sustainability to support competitiveness: from theory to practice. In C Silvestri, M Piccarozzi, B Aquilani (Eds.), Customer Satisfaction and Sustainability Initiatives in the Fourth Industrial Revolution, 99-124. IGI Global. ISBN: 9781799814191.

Mazzi A (2020) Introduction. Life cycle thinking. In J Ren, S Toniolo (Eds.), Life Cycle Sustainability Assessment for Decision-Making: Methodologies and Case Studies, 119. Elsevier. ISBN: 9780128183557.

Mazzi A, Toniolo S, Manzardo A, Ren J, Scipioni A (2016) Exploring the direction on the environmental and business performance relationship at the firm level. Lessons from a literature review. Sustainability 8(11): 1200. Doi=https://doi.org/10.3390/su81112 00 .

Ramage MH, Burridge H, Busse-Wicher M, Fereday G, Reynolds T, Shah DU, Wu G, Yu L, Fleming P, Densley-Tingley D, Allwood J, Dupree P, Linded PF, Sherman O (2017) The wood from the trees: The use of timber in construction. Renewable and Sustainable Energy Reviews 68(Feb): 333-359. Doi=https://doi.org/10.1016/j.rser.20 16.09.107.

Rockström J, Steffen W, Noone K, Persson Å, Chapin FS, Lambin E, Lenton TM, Scheffer M, Folke C, Schellnhuber HJ, Nykvist B, de Wit CA, Hughes T, der Leeuw S, Rodhe H, Sörlin H, Snyder PK, Costanza R, Svedin U, Falkenmark M, Karlberg L, Corell RW, Fabry VJ, Hansen J, Walker B, Liverman D, Richardson K, Crutzen P, Foley J (2009) Planetary boundaries: exploring the safe operating space for humanity. Ecology and Society 14(2): 32. Retrieved from http://www.ecologyandsociety.org/ vol14/iss2/art32/.

Rodriguez C, Parra C, Casado G, Minano I, Albaladejo F, Benito F, Sànchez I (2016) The incorporation of construction and demolition waste as recycled mixed aggregates in non-structural concrete precast pieces. Journal of Cleaner Production 127(Jul): 152161. Doi=https://bit.ly/36OtGr9.

Saghafi MD, Teshnizi ZSH (2011) Recycling value of building materials in building assessment system. Energy and Buildings 43(11): 3181-3188. DOI=https://doi.org/ 10.1016/j.enbuild.2011.08.016.

Sandin G, Peters GM, Svanstrom M (2014) Life cycle assessment of construction materials: the influence of assumption in the end-of-life modelling, International Journal of LCA 19(Dec): 723-731. Doi=https://doi.org/10.1007/s11367-013-0686-x.

Steffen W, Richardson K, Rockström J, Cornell SE, Fetzer I, Bennett EM, Biggs R, Carpenter SR, de Vries W, de Wit CA, Folke C, Gerten D, Heinke J, Mace GM, Persson LM, Ramanathan V, Reyers B, Sörlin S (2015) Planetary boundaries: guiding human development on a changing planet. Science 347(6223): 1259855. Doi=https:// doi.org/10.1126/science.1259855.

UN (2002) Plan of implementation of the world summit on sustainable development. United Nations, UN Documents, A/CONF.199/20. Retrieved from http://www.undocuments.net/jburgpln.htm.

UNEP (2013) Guidelines for national waste management strategies. Moving from challenges to opportunities. United Nations Environmental Program. ISBN: 978-92807-3333-4. Retrieved from http://cwm.unitar.org/national-profiles/publications/cw/ wm/UNEP_UNITAR_NWMS_English.pdf. 
Vasquez DZ, Bribiàn I Z, Jànez A (2016) Analysis of the environmental performance of life-cycle building waste management strategies in tertiary buildings. Journal of Cleaner Production 130(Sep): 143-154. Doi=https://doi.org/10.1016/j.jclepro.2016. 02.048 .

Vieira CS, Pereira PM (2015) Use of recycled construction and demolition materials in geotechnical applications: a review. Resources, Conservation and Recycling 103(Oct): 192-204. Doi=https://bit.ly/2FLc0Re.

WEF (2016) The building sector's trillion dollar circular economy opportunity. World Economic Forum. Retrieved from https://bit.ly/2tcddyo. 
